P.O. Gentsar, S.M. Levytskyi

\title{
Influence of Laser Radiation on Optical Properties of High Resistivity Crystals CdTe and Solid Solutions $\mathrm{Cd}_{1-\mathrm{x}} \mathrm{Zn}_{\mathrm{x}} \mathrm{Te}$
}

\author{
V.E. Lashkaryov Institute of Semiconductor Physics NAS of Ukraine, Kyiv, Ukraine,
}

e-mail: rastneg@isp.kiev.ua,levytskyi@ua.fm

\begin{abstract}
In this paper, the transmission and reflection spectra of $p$-CdTe (111) single crystals; solid solutions of $\mathrm{Cd}_{1-\mathrm{x}} \mathrm{Zn}_{\mathrm{x}} \mathrm{Te}(\mathrm{x}=0.1)$ in the range $(0.2-1.7) \cdot 10^{-6} \mathrm{~m}$ before and after laser irradiation at the wavelength $\lambda=532 \mathrm{~nm}$ in the energy range $(66-164) \mathrm{mJ} / \mathrm{cm}^{2}$ for CdTe (111) and in the energy range $46.6 \mathrm{~mJ} / \mathrm{cm}^{2}-$ $163.5 \mathrm{~mJ} / \mathrm{cm}^{2}$ for $\mathrm{Cd}_{1-\mathrm{x}} \mathrm{Zn}_{\mathrm{x}} \mathrm{Te}(\mathrm{x}=0.1)$ are measured. It is established that the main mechanism of influence of pulsed laser irradiation on the optical properties of thin surface layers of the investigated crystals is structural gettering, that is, the absorption due to the presence of sections of semiconductors that have a defective structure and have the ability to actively absorb point defects.
\end{abstract}

Key words: CdTe, CdZnTe, transmission, reflection, absorption, laser irradiation.

Received 31.08.2019; accepted for publication 15.03.2020.

\section{Introduction}

Semiconductor materials $\mathrm{A}^{\mathrm{II}} \mathrm{B}^{\mathrm{VI}}$, including CdTe and $\mathrm{Cd}_{1-\mathrm{x}} \mathrm{Zn}_{\mathrm{x}} \mathrm{Te}$, is one of the most promising materials that are used for different kinds of detectors of ionizing radiation [1-4].

\section{Experimental results and their discussion}

In this paper, the transmission and reflection spectra of single crystals $p$-CdTe (111) with specific resistivity $\rho=(2 \div 5) \cdot 10^{9} \Omega \cdot \mathrm{cm}$ are measured to elucidate the mechanisms of the influence of pulsed laser irradiation on thin surface layers of semiconductors; solid solutions $\mathrm{Cd}_{1-\mathrm{x}} \mathrm{Zn}_{\mathrm{x}} \mathrm{Te}(\mathrm{x}=0.1) \quad$ with specific resistivity $\rho=(0.5 \div 3) \cdot 10^{10} \Omega \cdot \mathrm{cm}$ in the range $(0.2-1.7) \cdot 10^{-6} \mathrm{~m}$ before and after laser irradiation at the wavelength of $\lambda=532 \mathrm{~nm}$ in the energy range $66-164 \mathrm{~mJ} / \mathrm{cm}^{2}$ for $\mathrm{CdTe}(111)$ and in the energy range $46.6-163.5 \mathrm{~mJ} / \mathrm{cm}^{2}$ for solid solutions $\mathrm{Cd}_{1-\mathrm{x}} \mathrm{Zn}_{\mathrm{x}} \mathrm{Te}(\mathrm{x}=0.1)$.

In Fig. 1 shows the optical transmission spectra of $T=f(\lambda)$ single crystals of $p$-CdTe (111) with a specific resistance of $(2 \div 5) \cdot 10^{9} \Omega \cdot \mathrm{cm}$ (original sample is curve 1 and the samples are irradiated with energy of $66 \mathrm{~mJ} / \mathrm{cm}^{2}$; $108 \mathrm{~mJ} / \mathrm{cm}^{2}, 164 \mathrm{~mJ} / \mathrm{cm}^{2}$ - curves 2-4 respectively). As can be seen from the figure, the transmittance of single crystals of $p$-CdTe (111) decreases only when irradiated with an energy density of $108 \mathrm{~mJ} / \mathrm{cm}^{2}$. In laser processing of these samples energy densities of $66 \mathrm{~mJ} / \mathrm{cm}^{2}$ and $164 \mathrm{~mJ} / \mathrm{cm}^{2}$ transmittance is almost identical to that of the original samples. This experimental fact shows that in this laser treatment of single crystals of $p$-CdTe (111) in the optical spectra the main role is played by thin surface layers of the investigated material, i.e. changes occurring near the surface of the semiconductor material. 


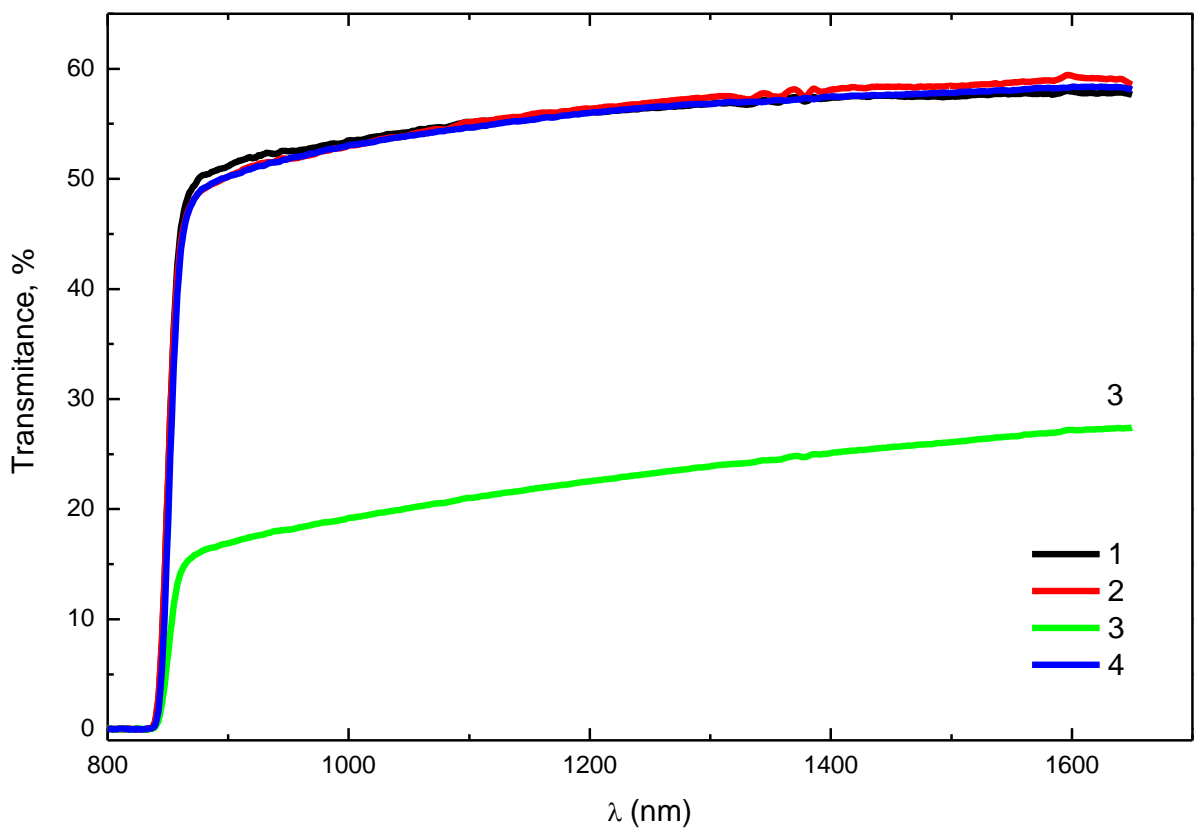

Fig. 1. Transmission spectra of single crystals $p$-CdTe (111): original sample is curve 1 and the samples are irradiated with energy of $66 \mathrm{~mJ} / \mathrm{cm}^{2} ; 108 \mathrm{~mJ} / \mathrm{cm}^{2}, 164 \mathrm{~mJ} / \mathrm{cm}^{2}$ - curves $2-4$ respectively.

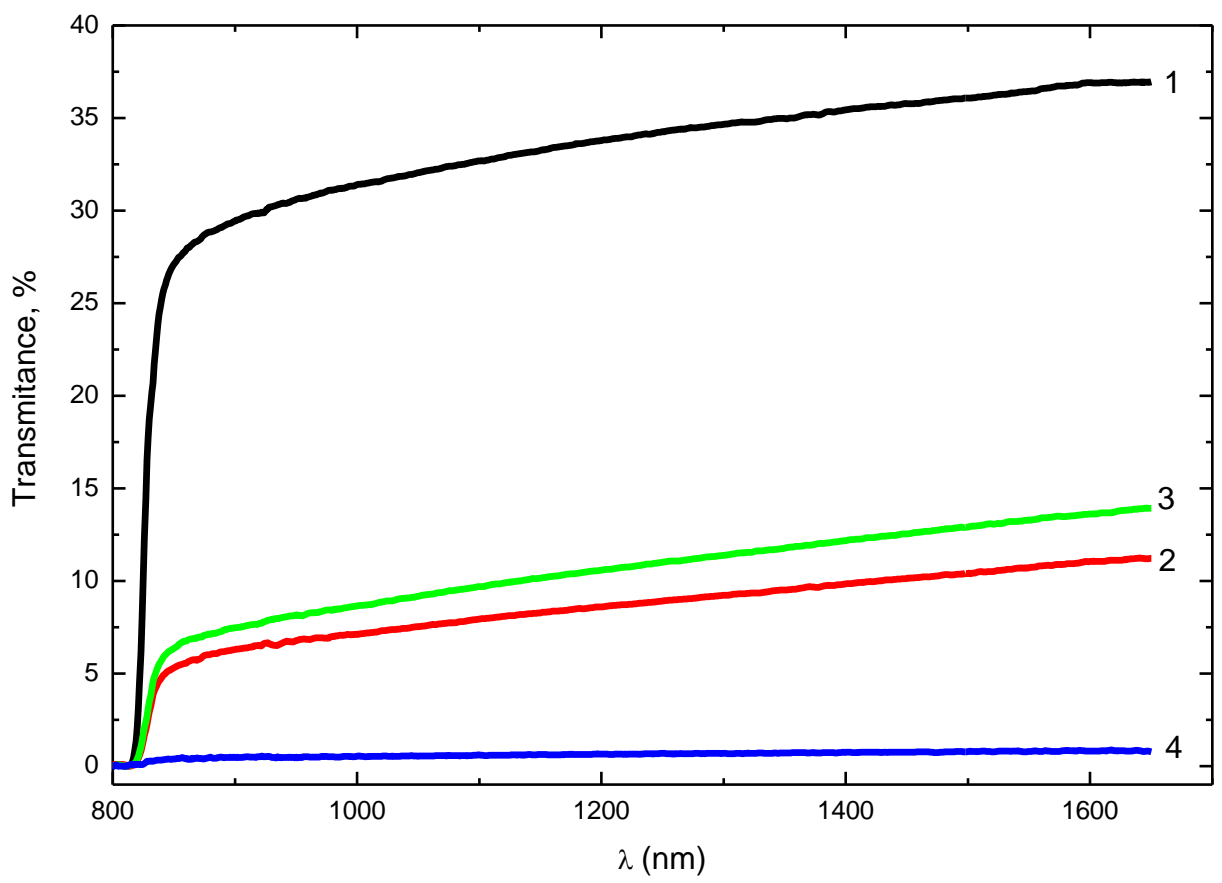

Fig. 2. Transmission spectra of solid solutions $\mathrm{Cd}_{1-\mathrm{x}} \mathrm{Zn}_{\mathrm{x}} \mathrm{Te}(\mathrm{x}=0.1)$ : original sample is curve 1 and the samples are irradiated with energy of $46.66 \mathrm{~mJ} / \mathrm{cm}^{2} ; 102.3 \mathrm{~mJ} / \mathrm{cm}^{2}, 163.5 \mathrm{~mJ} / \mathrm{cm}^{2}$ - curves 2-4 respectively.

In Fig. 2 shows the optical transmission spectra of $T=f(\lambda)$ solid solutions $\mathrm{Cd}_{1-\mathrm{x}} \mathrm{Zn}_{\mathrm{x}} \mathrm{Te}(\mathrm{x}=0.1)$ with a specific resistance of $(0.5 \div 3) \cdot 10^{10} \Omega \cdot \mathrm{cm}$ (original sample is curve 1 and the samples are irradiated with energy of $\quad 46.66 \mathrm{~mJ} / \mathrm{cm}^{2} ; \quad 102.3 \mathrm{~mJ} / \mathrm{cm}^{2}$, $163.5 \mathrm{~mJ} / \mathrm{cm}^{2}$ - curves $2-4$ respectively). As can be seen from the figure, the irradiation of solid solutions of $\mathrm{Cd}_{1}$. ${ }_{x} \mathrm{Zn}_{\mathrm{x}} \mathrm{Te}(\mathrm{x}=0.1)$ with energy densities of $46.66 \mathrm{~mJ} / \mathrm{cm}^{2}$ and $102.3 \mathrm{~mJ} / \mathrm{cm}^{2}$ significantly reduces the transmittance of this solid solution compared to the original samples, and with laser processing the energy density of $163.5 \mathrm{~mJ} / \mathrm{cm}^{2}$ solid solutions of $\mathrm{Cd}_{1-\mathrm{x}} \mathrm{Zn}_{\mathrm{x}} \mathrm{Te}(\mathrm{x}=0.1)$ transmittance is practically zero (curve 4 ).

In $[5,6]$ it was observed that the spectra of optical reflection (Figs. 3, 4) of single crystals of $p$-CdTe (111) and solid solutions $\mathrm{Cd}_{1-\mathrm{x}} \mathrm{Zn}_{\mathrm{x}} \mathrm{Te}(\mathrm{x}=0.1)$ showed that at a given laser treatment there is a laser-stimulated increase in the reflectivity of these semiconductor materials (the 
integral effect is explained by the differences in the optical characteristics of the surface layer and the volume material, that is, the complex refractive index of the surface layer $\tilde{n}_{s}=n_{s}+i \chi_{s}$ is different from the complex refractive index of the volume material $\left.\tilde{n}_{v}=n_{v}+i \chi_{v}\right)$.

Since the reflection coefficient $R=f(\lambda)$ is related to the transmittance $T=f(\lambda)$ and the absorption coefficient $D=f(\lambda)$ by the ratio $R+T+D=1$ (thus the scattering of the light wave in the sample is not taken into account), the absorption spectra $D=1-(R+T)$ of the light (electromagnetic) wavelength $\lambda$ are also constructed in this paper.

The constructed optical absorption spectra $D=[1-(T+R)]=f(\lambda)$ of these materials are completely correlated with the optical transmission spectra $T=f(\lambda)$ and the reflection $R=f(\lambda)$. From the absorption spectra (Fig. 5, 6) of the material shows that the lower energies, i.e. at the energies of light (electromagnetic) waves $E$ which is much lower than the fundamental optical transition energy $E_{0}$, absorption of single crystals $p$-CdTe (111) after laser treatment with an energy density of $66 \mathrm{~mJ} / \mathrm{cm}^{2}$ and $164 \mathrm{~mJ} / \mathrm{cm}^{2}$ becomes smaller compared

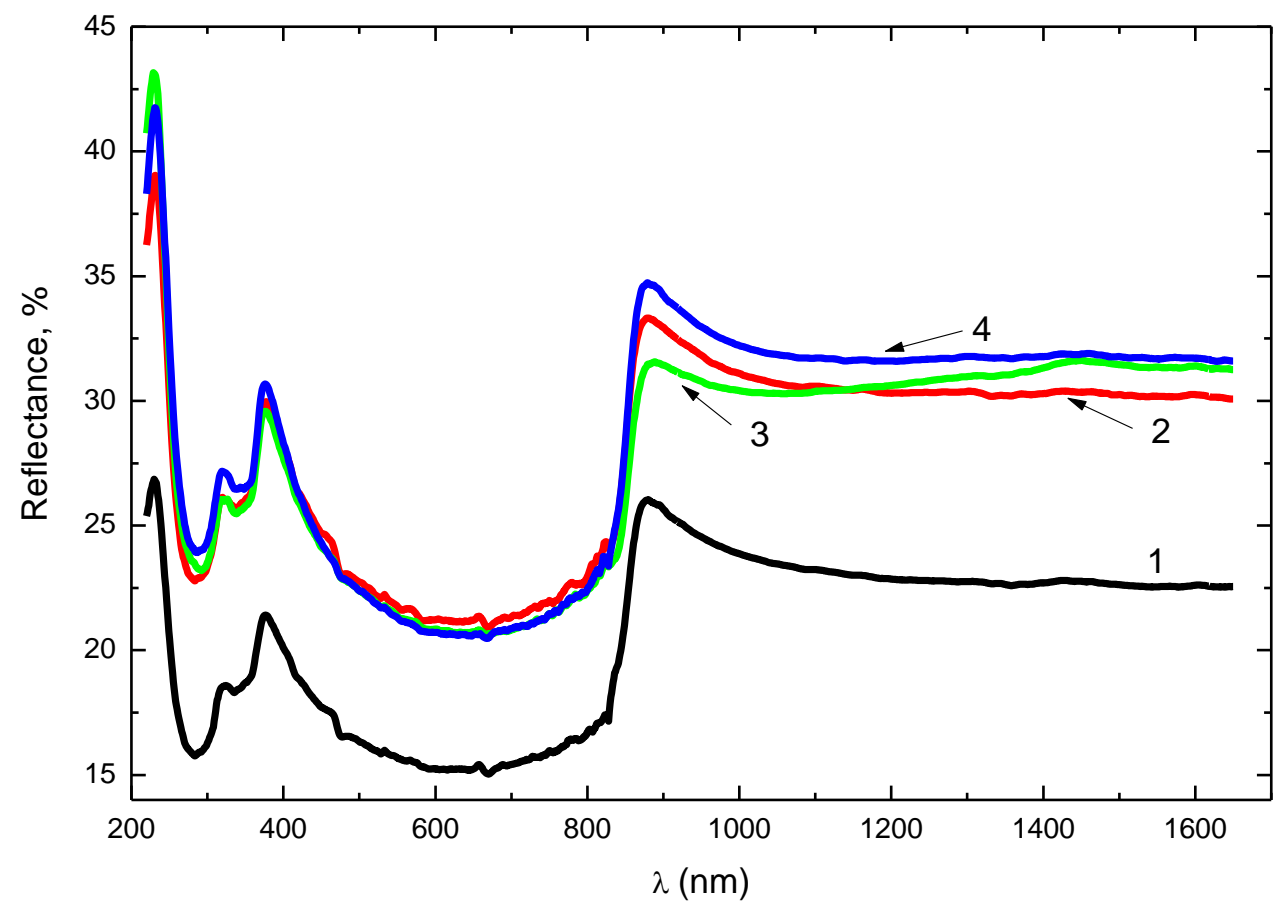

Fig. 3. Reflection spectra of single crystals $p$-CdTe (111): original sample is curve 1 and the samples are irradiated with energy of $66 \mathrm{~mJ} / \mathrm{cm}^{2} ; 108 \mathrm{~mJ} / \mathrm{cm}^{2}, 164 \mathrm{~mJ} / \mathrm{cm}^{2}$ - curves $2-4$ respectively.

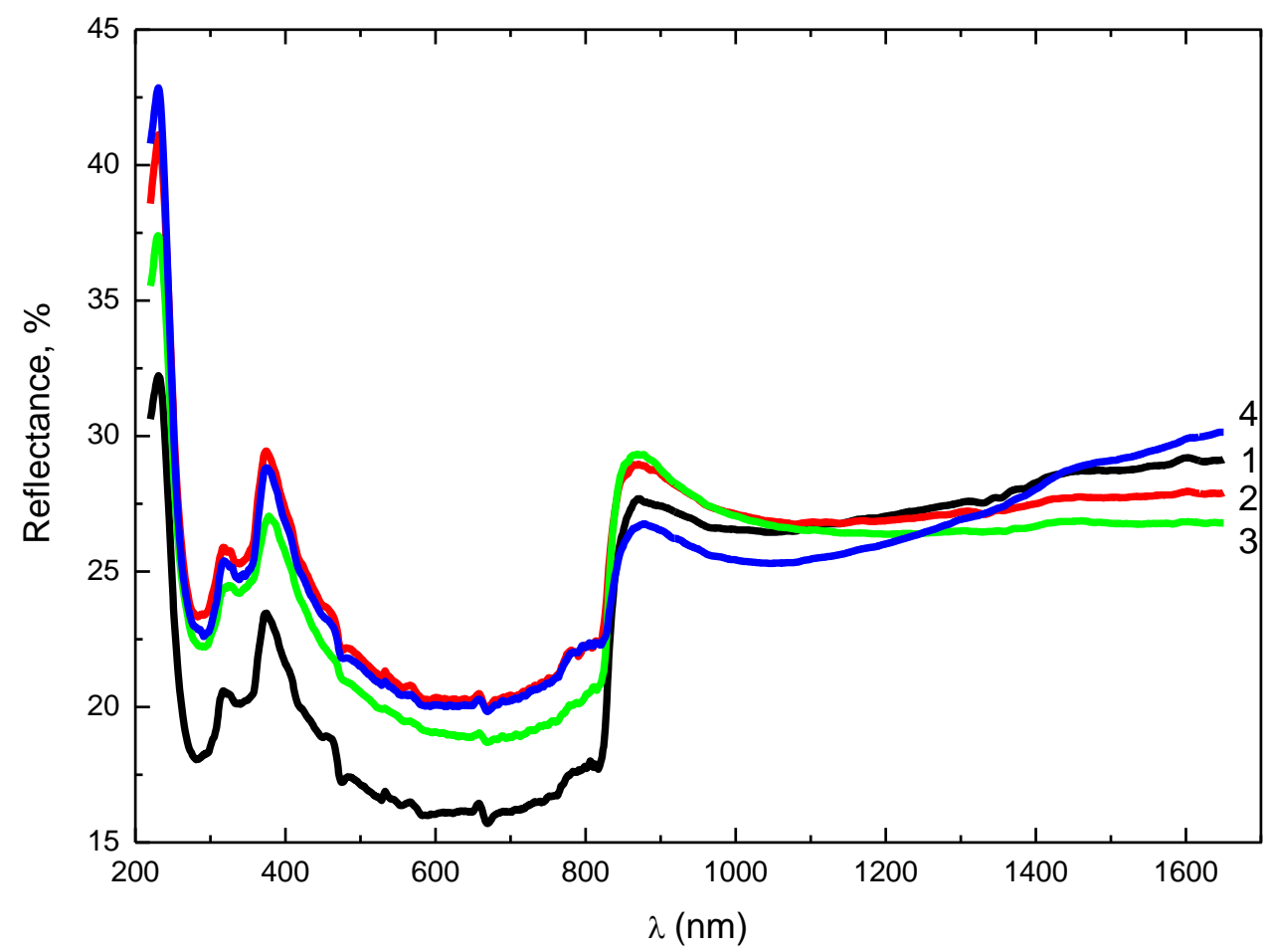

Fig. 4. Reflection spectra of solid solutions $\mathrm{Cd}_{1-\mathrm{x}} \mathrm{Zn}_{\mathrm{x}} \mathrm{Te}(\mathrm{x}=0.1)$ : original sample is curve 1 and the samples are irradiated with energy of $46.66 \mathrm{~mJ} / \mathrm{cm}^{2} ; 102.3 \mathrm{~mJ} / \mathrm{cm}^{2}, 163.5 \mathrm{~mJ} / \mathrm{cm}^{2}$ - curves $2-4$ respectively. 
to the original samples (Fig. 5 curves 1, 2, 4). In laser processing of single crystals $p$-CdTe (111) with an energy density of $108 \mathrm{~mJ} / \mathrm{cm}^{2}$, the absorption of the samples is significantly increased (Fig. 5 curve 3). For solid solutions of $\mathrm{Cd}_{1-\mathrm{x}} \mathrm{Zn}_{\mathrm{x}} \mathrm{Te}(\mathrm{x}=0.1)$, the absorption of the samples is significantly increased by laser treatment with energy densities of $46.6 \mathrm{~mJ} / \mathrm{cm}^{2} ; 102.3 \mathrm{~mJ} / \mathrm{cm}^{2}$; $163.5 \mathrm{~mJ} / \mathrm{cm}^{2}$ compared to the original samples (Fig. 6, curves 1-4).

Based on the Heisenberg uncertainty principle for energies $E$ and time $t(\Delta E \cdot \Delta t \geq \hbar)$, the relaxation effects in light absorption by a crystal are described by the expansion parameter $\Delta E=\hbar / \tau$ (the broadening of the electronic transition $E_{0}$ is related to the free charge carrier life due their interaction with lattice vibrations, impurities, defects including surface character), where $\tau$ is the time of energy relaxation of the photo-generated steam.

According to the experimental data on the optical transmission and reflection spectra (Figs. 1-4) for single crystals $p$-CdTe (111) with specific resistance of $(2 \div 5) \cdot 10^{9} \Omega \cdot \mathrm{cm}$ and solid solutions $\mathrm{Cd}_{1-\mathrm{x}} \mathrm{Zn}_{\mathrm{x}} \mathrm{Te}(\mathrm{x}=0.1)$ with a specific resistance of $(0.5 \div 3) \cdot 10^{10} \Omega \cdot \mathrm{cm}$ the energy expansion of the optical spectra of these materials is $0.049 \mathrm{eV} ; 0.075 \mathrm{eV}$, respectively.

Energy relaxation time of photogenerated pairs $\tau$ for single crystals single crystals $p$-CdTe (111) and solid solutions $\mathrm{Cd}_{1-\mathrm{x}} \mathrm{Zn}_{\mathrm{x}} \mathrm{Te}(\mathrm{x}=0.1)$ is equal to $1.343 \cdot 10^{-14} \mathrm{~s}$ and $0.878 \cdot 10^{-14} \mathrm{~s}$ respectively.

According to the literature data [7-9], the oxide coatings of the surfaces of the investigated materials are

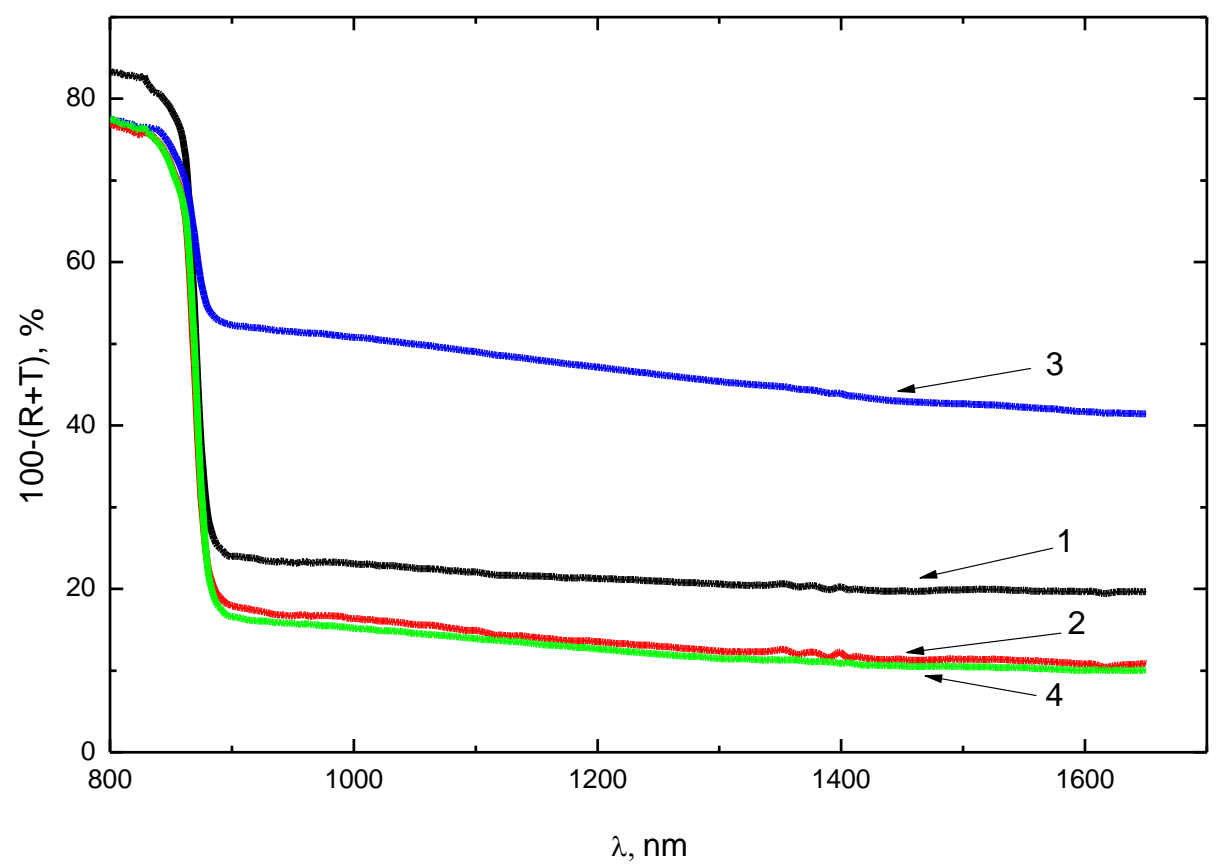

Fig. 5. Absorption spectra of single crystals $p$-CdTe (111): original sample is curve 1 and the samples are irradiated with energy of $66 \mathrm{~mJ} / \mathrm{cm}^{2} ; 108 \mathrm{~mJ} / \mathrm{cm}^{2}, 164 \mathrm{~mJ} / \mathrm{cm}^{2}$ - curves 2-4 respectively.

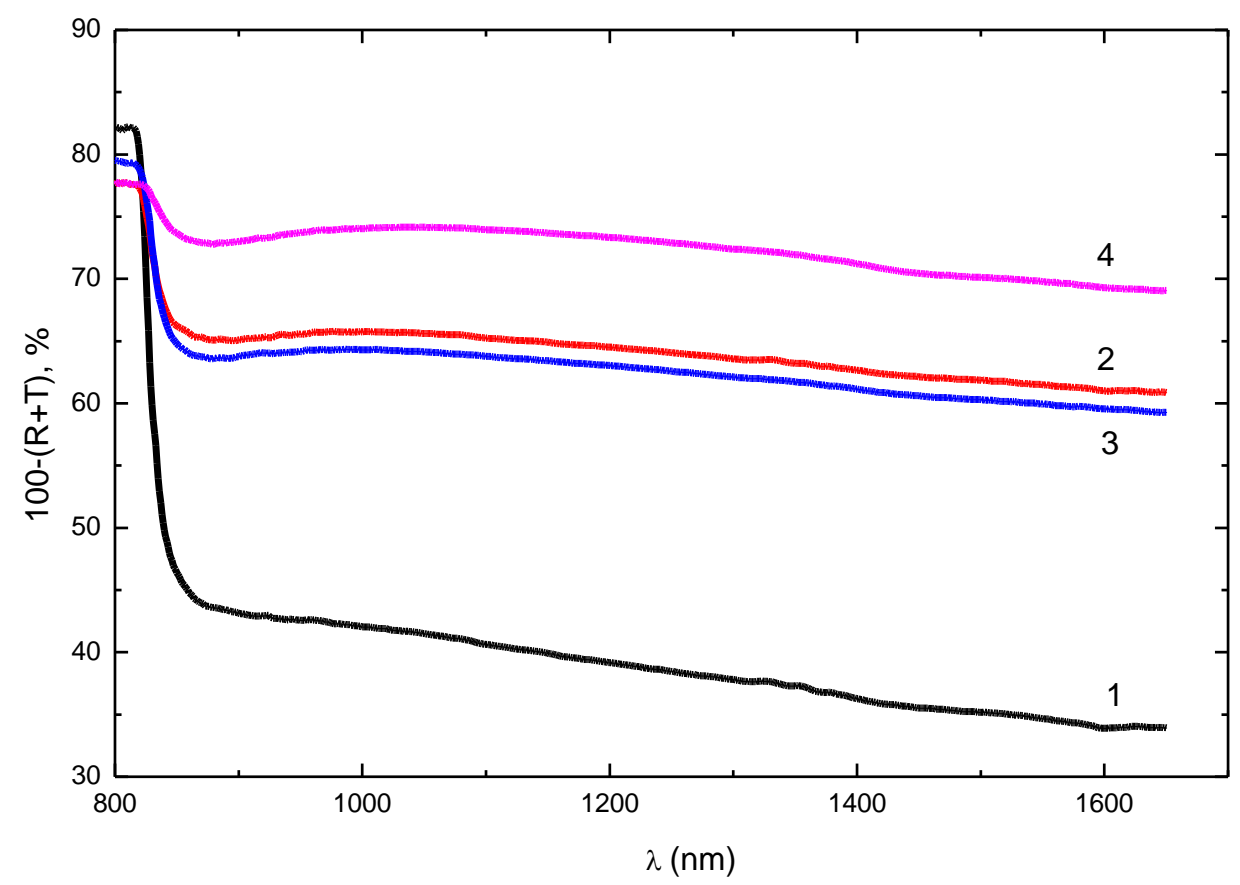

Fig. 6. Absorption spectra of solid solutions $\mathrm{Cd}_{1-\mathrm{x}} \mathrm{Zn}_{\mathrm{x}} \mathrm{Te}^{71}(\mathrm{x}=0.1)$ : original sample is curve 1 and the samples are irradiated with energy of $46.66 \mathrm{~mJ} / \mathrm{cm}^{2} ; 102.3 \mathrm{~mJ} / \mathrm{cm}^{2}, 163.5 \mathrm{~mJ} / \mathrm{cm}^{2}$ - curves $2-4$ respectively. 
amorphous films, the thickness of which ranges from 0.5 to $0.7 \mathrm{~nm}$. It should be noted that at the interface of the semiconductor-oxide there is a transition layer of oxide.

\section{Conclusions}

Experimental studies have shown that the main mechanism of influence of pulsed laser irradiation on the optical properties of thin surface layers of the investigated crystals is structural gettering, that is, the absorption due to the presence of sections of semiconductors that have a defective structure and have the ability to actively absorb defects. In single crystals $p$-CdTe (111) and solid solutions $\mathrm{Cd}_{1-\mathrm{x}} \mathrm{Zn}_{\mathrm{x}} \mathrm{Te}(\mathrm{x}=0.1)$ the role of hetero play cadmium, tellurium, zinc and their complexes.

Gentsar P.O. - Senior Research Fellow; Levytskyi S.M. - Senior Research Fellow.

[1] D.V. Korbutyak, S.V. Melnychuk. E.V. Corbut, M.M. Borysyuk, Cadmium telluride: impurity-defect states and detector properties (Ivan Fedorov, Kyiv, 2000).

[2] V.I. Khivrich, Effects of compensation and penetrating radiation in CdTe single crystals (Institute for Nuclear Research, Kyiv, 2010).

[3] T.E. Schlesinger, J.E. Toney, H. Yoon, E.Y. Lee, B.A. Brunett, L. Franks, R.B. James, Materials Science and Engineering, 32, 103 (2001) (https://doi.org/10.1016/S0927-796X(01)00027-4).

[4] V.A. Gnatyuk, T. Aoki, O.I. Vlasenko, S.N. Levytskyi, 2011 IEEE Nuclear Science Symposium and Medical Imaging Conference Record (NSS/MIC), (IEEE, Valencia, 2011), p. 4506.

[5] P.O. Gentsar, O.I. Vlasenko, S.M. Levytskyi, V.A. Gnatyuk, PCSS, 15 (4), 856 (2014).

[6] P.O. Gentsar, O.I. Vlasenko, S.M. Levytskyi, V International Scientific and Practical Conference on Semiconductor Materials, Information Technologies and Photovoltaics (SMITP-2018), (Kremenchuk Mykhaylo Ostrogradsky National University, Kremenchuk, 2018), p. 12.

[7] F. Bechstedt, R. Enderline, Surfaces and Boundaries of the Semiconductor Division (Mir, Moscow, 1990).

[8] Problems of surface physics of semiconductors (Naukova Dumka, Kyiv, 1981).

[9] V.E. Primachenko, O.V. Snitko, Physics of a metal-doped semiconductor surface (Naukova Dumka, Kyiv, 1988).

\title{
П.О. Генцарь, С.М. Левицький
}

\section{Вплив лазерного опромінення на оптичні властивості високоомних кристалів CdTe та твердих розчинів $\mathrm{Cd}_{1-\mathrm{x}} \mathrm{Zn}_{\mathrm{x}} \mathrm{Te}$}

\author{
Інститут фізики напівпровідників ім. В.С. Лашкарьова НАН Украӥни, Київ, Украӥна, \\ e-mail: rastneg@isp.kiev.ua,levytskyi@ua.fm
}

\begin{abstract}
В даній роботі проведено оптичні дослідження спектрів пропускання та відбивання монокристалів $p$-CdTe (111); твердих розчинів $\mathrm{Cd}_{1-\mathrm{x}} \mathrm{Zn}_{\mathrm{x}} \mathrm{Te}(\mathrm{x}=0,1)$ в діапазоні $(0,2-1,7) \cdot 10^{-6}$ м до та після лазерного опромінення на довжині світлової хвилі $\lambda=532$ нм в інтервалі енергій $66-164$ мДж/см² для СdTe(111) та

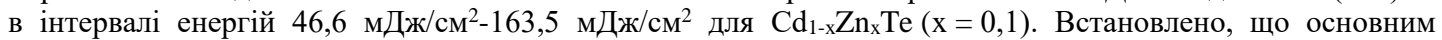
механізмом впливу імпульсного лазерного опромінення на оптичні властивості тонких приповерхневих шарів досліджених кристалів є структурне гетерування, тобто поглинання, обумовлене наявністю ділянок напівпровідників що мають дефектну структуру і володіють здатністю активно поглинати точкові дефекти і зв’язувати домішки.
\end{abstract}

Ключові слова: CdTe, CdZnTe, пропускання, відбивання, поглинання, лазерне опромінення. 